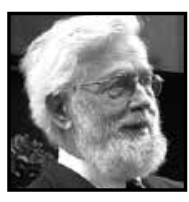

\title{
Commentary \\ Looking Back at a Landmark Study About Why Teachers Matter
}

\section{Eigil Pedersen}

\section{ABSTRACT}

A researcher in education usually asks questions, selects a random sample, conducts an experiment, and publishes the findings. However, my questions arose from my actual experiences, first as a pupil, and later as a teacher in an elementary school located in a Montreal slum. Examination of the pupils' permanent record cards indicated that their IQs typically changed between grades three and six. Moreover, the records showed that the efforts of Miss A had not only resulted in the significantly higher IQs of her pupils compared to those of other grade one teachers, but years later, interviews of the same individuals also indicated higher rankings with respect to their subsequent adult status.

\footnotetext{
his commentary looks back at a study published in the 1978 Harvard Educational Review. The methodology of that study was unusual at that time. That work was based on existing data, and then on new data collected by interviewing and also by observing respondents. The whole project arose out of my personal experiences.
}

I graduated from McGill's School for Teachers in 1952. By July 1958, I had taught Grades Five to Seven for five years in Little Burgundy, and had completed one year as a high school biology teacher at Northmount High. I was halfway through the course requirements for McGill's new part-time M.A. in Education. The School for Teachers had an unexpectedly high enrolment for the coming fall, and I was asked to help out as a lecturer for just one year. One year became five, and ultimately thirty-three! Because I 
had scant qualifications for the work, I was asked to teach courses in subjects no other faculty members felt qualified to offer. I soon realized that, despite my age and large and growing family, I had to earn a doctorate. I was struck by the fact that most teacher education theories had arisen from psychological studies of the characteristics of pupils rather than of schools. I felt I could find my own specialty in the Sociology of Education. In 1963, I was accepted into a doctoral program at Harvard University, and given a leave of absence from McGill University.

After I had completed all the requirements for my Ed. D. degree in 1966, I returned to McGill to resume my career there in the Faculty of Education's Department of Psychology and Sociology of Education, newly renamed to include my new specialty. Just days after my return, I learned that the Quebec Government had established the Institut de Recherche Pédagogique (IRP) and that I had been appointed to its advisory board. As I attended meetings it occurred to me to study the permanent record cards of children who had attended the elementary school in which I had been a pupil from Kindergarten to Grade Four, and where I had later taught grades five to seven, from 1952 to 1957. The principal there allowed me to photocopy more than 300 permanent record cards of my former pupils.

I applied for research funds from the IRP. The Director asked me, "What is your research question?" My answer was that I didn't have a research question yet. Then I was asked, "Where is your random sample?" My answer was that children don't grow up in random samples, but rather, experience the effects of living in particular socioeconomic and ethnic, or even racial neighbourhoods or ghettoes, which provide unique experiences that certainly influence their development. There were other similar questions concerning my null hypothesis, my control group, and the like, all suggesting that research methods based on the overwhelming influence of psychology and psychologists on educational research were the only way to go. I was told that my proposal looked more like a fishing expedition than a serious research project! What would people think of the IRP granting funds to a member of its own advisory board for such an unscientific proposal? No funds were granted, and I was obliged to support the research from my own resources.

This lack of funding put severe restraints on what I could hope to achieve. It also delayed my work, and this delay was exacerbated by emerging responsibilities at McGill, including my being elected as my faculty's representative on the University Senate, my appointments as Chair of my Department, later as Dean of Students, and after that, as Vice-Principal (Academic) from 1972 to 1981. These challenges kept me very busy, both on and off campus, and so it was not until 1977 that I was able to co-author ${ }^{1}$ an article on 
this research, which was published in the Harvard Educational Review under the title "A New Perspective on the Effects of First-Grade Teachers on Children's Subsequent Adult Status" (Pedersen, Faucher, \& Eaton, 1978). This article has been frequently cited in the literature every year since its publication.

Those who are familiar with the above publication will remember that the school was located in a slum district of a large city where two major railways were headquartered. I can now inform you that this was Royal Arthur School located in Montreal on Canning Street just south of the CNR tracks and north of Notre Dame Street. The families of Black pupils lived there because of railway careers that were open to their fathers, such as Porter (Red-Cap) and Dining or Sleeping Car Attendant. Of course, a negative aspect worth remembering is that it was almost impossible then for male members of this visible racial minority to find decent work anywhere else in the city. They had their own church, community center, recreational centers-in short, they lived there because careers were available, but also because it was their own community. The very much larger group of "Whites" who lived there had very little, if any, sense of community. The vast majority of them were there because the rents for housing were among the cheapest in the city.

Four times during the school year, their teachers presented the children with report cards to take home to their parents, showing their grades on tests of the academic subjects such as Reading, Handwriting, Arithmetic, French Language, English Literature, and the like, as well as teacher estimates for each pupil of five personality characteristics, namely Reliability, Leadership, Industry, Initiative, and Cooperation. The grades were: E (excellent), VG (very good), G (good), F (fair), and U (unsatisfactory). Parents were required to sign and return these report cards. At the end of the school year, each teacher summarized the grades from the four report cards and entered them on the pupils' permanent record cards.

The School Board required the formal administration of two IQ tests to all pupils, the first in Grade Three and the second in Grade Six. Therefore, almost all of the permanent record cards also included the results of two IQ tests for each pupil taken three years apart. I was startled at what I found in my "fishing expedition." At The School for Teachers, I had learned that since intelligence was inborn and permanent, changes in IQ result from error of measurement, and are usually relatively small, within five points. However, these cards showed some very large differences in the two IQ scores for many of the pupils. And so, even though I interpreted differences in scores of plus or minus five points as indicating no change, still a majority of pupils experienced IQ change, up or down, increase or decrease. 
Measured IQ change of more than five points between Grades Three and Six was the norm, not the exception. Does intelligence change? The idea of neuroplasticity had not yet been widely accepted. So how were we to account for these large changes in IQ?

Further analyses showed that the directions and magnitude of the changes recorded on the permanent record cards were statistically different for pupils of different Grade One teachers beyond the .05 level of probability. Because anonymity was required by the Harvard Educational Review, we named three long-serving teachers Miss A, Miss B, and Miss C. Table 1 of the article shows that the patterns of IQ change for the former pupils of these three grade one teachers were statistically significant beyond the .05 level. Table 3 shows that the percent of Miss A's pupils who increased in IQ was 33 for boys and 38 for girls; this difference by gender was not statistically significant. The percents of IQ increase for Miss C's former pupils was 12 for boys and 13 for girls-much smaller than for pupils of Miss A. In fact, Miss C's girls and boys were between three and four times more likely to decrease in IQ than to increase. The differences in IQ change for girls as compared to boys was not significant for either Miss A and Miss C. However, former pupils of Miss A were significantly more likely to experience IQ increase than those of Miss $C$.

The pattern for Miss B's pupils was different. Her former girls were more than twice as likely to increase in IQ than her former boys. The pattern of increase for her boys was 18 percent, whereas for her former girls, it was more than double that, at 39 percent! This difference is statistically significant at the .02 level of probability. Putting it another way, the probability of the subsequently lower IQ change of Miss B's boys as compared to that of her girls having occurred by chance was smaller that one in fifty!

On a personal note: I was a boy in Miss B's Grade One Class in 1935-36. I sat near the back of Row 2.

Except for the kindergarten, all the classrooms in Royal Arthur School had six rows of eight cast-iron and wood desks with fold-up seats, all securely screwed to the floor. Miss B's seating policy was: girls in the first four seats of each row, and boys in the last four. Could IQ change and its direction of change up or down be influenced by where a grade one teacher required the pupils to sit in the classroom? Did she seat them like that because she had different expectations of girls than boys? Having seated them differently, did she treat the boys differently from the girls in other ways? Don't most of us? Did this influence their behaviours and achievements in other ways? Would these differences show up in later adult achievement? 
On another personal note: It wasn't until several years later that my choirmaster at the church where I was then singing asked me: "Pedersen, why are you reading the music with your nose?" He arranged and paid for the eye examination and the glasses, which the examination showed that I needed. I still remember vividly my astonishment with the amazing improvement of my ability to see. Why hadn't Miss B or any of my other teachers noticed my problem? My choirmaster had never experienced any teacher education.

I remember my Kindergarten and Grade One teachers at Royal Arthur School, and their names as well. I have no recollection of any of the others. I do remember the Principal, and his name, probably because when I was in Grade Four, he gave me the strap, four on each hand.

In the spring of that year, 1939, after I had completed Grade Four, our family was evicted from our small flat on St. Antoine Street near the corner of Atwater Avenue, on the grounds of our not having paid the rent. We had hit rock bottom, or so it seemed. We moved to two upstairs rooms in a derelict old house on Argyle Avenue. The one at the back of the house was chosen for my parents, and the other at the front, overlooking the CPR railway tracks, I shared with my older sister. Argyle Avenue still has the same houses on its north side, and the CPR elevated tracks leading to and from Windsor Station on the south side. We might have hit bottom, but we were on the other side of the tracks, and therefore required to attend a different school.

Royal Arthur School had been a horrible experience for me. Meanwhile, going to Victoria School was the opposite. I suppose if I had not had to endure five years at the former school, the latter might not have seemed so wonderful. I still remember my teachers and the principal there with great affection and gratitude. How both organizations could be categorized by the same name-school-was beyond me. And unlike St. Antoine Street, Argyle Avenue was a lively social community. As my future unfolded, having been evicted from our flat on St. Antoine Street turned out to one of the best things that ever happened to me, and was certainly the beginning of a completely new and infinitely better life!

These above paragraphs may seem a bit self-indulgent, but I think that they go some way to explain some reasons for my firm conviction that the contexts of experience are at least as important as the personal characteristics of the children in understanding academic achievements, and ultimately improving them. 
Let us go back to the research. Not only were Miss A's boys and girls more likely to increase in IQ between Grade Three and Grade Six than those of the other two teachers, but also their mean achievement test scores and teacher estimates of their personality characteristics were higher in almost every subsequent grade. This led us to the question: Did Miss A's positive influence lead to higher achievement in adulthood as well?

As the above-mentioned report describes in detail, I decided to find former pupils, now grown up, employed, and raising their own families, and to interview them in depth to determine their adult status, high or low, and its schooling antecedents. With the help of experts, we created an Index of Adult Status Characteristics, which enabled us to rank the success of the respondents based on their answers to questions by the subjects and observations made by the interviewers on matters such as home ownership or not, income, the level of occupational prestige, the level of schooling completed, and also the appearance, quality of language used, and similar characteristics of the former pupils being interviewed.

Again, deliberately ignoring the idea of random samples, I was able to locate 60 former pupils for in-depth interviews. These consisted of 10 men and 10 women whose IQs had increased dramatically, another 20 whose IQs had changed little or none at all, and another 20 whose IQs had decreased between Grade Three and Six by wide margins. I thought of this as purposeful sampling, rather than random sampling. The question was: Is Adult Status significantly related to changes in IQ that had occurred years before during the time that they attended elementary school?

The statistical procedure called Path Analysis is often used to tease out the unknown order of occurrence of antecedent variables in events that happen over long periods of time. In the Path Analyses reported in our 1978 article, we were able to report on the influences of school achievement variables on the adult status of pupils in their actual known order of occurrence. Hence, correlation coefficients were calculated for the relationships of background factors such as father's occupational status, the number of children in the family, and the Grade One teacher; this showed that the impact of the Grade One teacher on the General Standing of pupils by the end of Grade Two was the strongest of those three predictor variables. Furthermore, the analysis showed that the General Standing of the pupils at the end of Grade Two was strongly predictive of their positive personality characteristics (Reliability, Leadership, Industry, Initiative, and Cooperation) in Grades Three to Grade Six, and that in the chain of influences, these impacted strongly and positively on General Standing in Grade Seven, which in turn had a powerful impact on Adult Status-almost as strong as the Grade One teacher's 
direct influence on Adult Status. The analysis suggested that the positive impact of the Grade One teacher on subsequent achievement variables in school was what led to the significantly higher achievement of Miss A's pupils in adult life than that of those of the other two grade one teachers.

Pupils were assigned to Grade One Teachers in Royal Arthur School on the basis of the alphabetic order of the first initial of their last names. This policy was meant to provide each teacher with an unbiased and fair share of all pupil types-good, bad, or indifferent. Those fortunate enough to have been assigned to Miss A received a better quality of teaching than those assigned to others, and for most of them, this had an impact on their personal development, academic achievement, and adult status in later life.

Good scores on Reliability, Leadership, Industry, Initiative, and Cooperation related positively and strongly to General Standing in Grade Seven, but not to Adult Status. Why not? Subsequent analyses suggested that while all of these variables were seen as positive by the teachers in the school, they were not all seen that way in the world of adult employment. In a post-publication analysis, which unfortunately disappeared along with the loss of the computer data tape, I looked at how separate personality characteristics were seen by prospective employers; I learned that in contrast to teachers, employers were looking for different personal characteristics in "Black" than in "White" job applicants. It seems that for "White" applicants they were seeking leadership and initiative, whereas for "Black" applicants, they were looking for reliability, industry, and cooperation. We had combined these estimates into one, and while that made sense in the world of the school, it did not in the outside world of employment. Apparently, employers at that time did not look for the same personality characteristics in "Black" candidates as they did in "White" candidates. I wonder if it has changed to this day? What I am speculating about here was the job situation at that time in Montreal, and not in some large city in the southern half of the United States!

A final few words about Miss A (see also Fallon, 2001). Miss A was the daughter of immigrants, probably from Appuglia, Italy, judging from her name, which was lole Appugliese. The pupils found this name difficult to pronounce, and so she was known to all of them as Miss Appledaisy. She was serious, strict, and fair. She was determined that every child in her class would learn to read, no matter what effort it took, or what methods would have to be devised. Unfortunately, she didn't start teaching at Royal Arthur School until after I had left that school as a pupil, or I might have been lucky enough to have had her as my Grade One teacher. But Miss Appledaisy and I were good colleagues for the five years during which I later taught at that school. lole was 
a fine organist and pianist, and every year on the last day of school before Christmas, all of the pupils and teachers would gather in the full length of the first-floor hall, just below the five steps leading up to the location of the gymnasium, which had been built onto the existing school building as an addition. The piano would be brought from the kindergarten to the area just above the top step, where Miss Appledaisy could be seen and heard by all. Most pupils saw their Grade One teacher in action during their first year in school. But those lucky enough to have been assigned to Miss Appledaisy had something in addition. They saw her in action, if only briefly, during each of the six years following Grade One. One of the questions we asked the adults during their interviews was, "Who was your Grade One teacher?" A substantial number of them identified Miss Appledaisy, even though the permanent record cards showed them to be wrong! Wishful thinking?

Miss Appledaisy was fluent in three languages, Italian, French, and English. By the time we had discovered all of these good things about her, she had become ill with cancer. She retired from teaching and spent her last days as a volunteer translator in one of the large Montreal hospitals. We were able to show her the results of this study before the publication of the article. She was proud and gratified.

And all this new knowledge from a fishing expedition!

\section{Note}

1. Thérèse Annette Faucher was a researcher at the Ministère de l'Éducation du Québec. She was also a co-author of mine on a 1971 book entitled, "Status and Prospects of Educational Research in Quebec." William W. Eaton was an Assistant Professor of Sociology at McGill University who lent his statistical expertise to the study.

\section{References}

Fallon, D. (2001). The amazing Miss A and why we should care about her. University of South Carolina Homecoming, College of Education, October 19, 2001.
Pedersen, E., Faucher, T.A., \& Eaton, W.W. (1978). A new perspective on the effects of firstgrade teachers on children's subsequent adult status. Harvard Educational Review, 48(1) 1-31. 


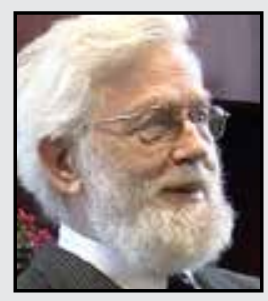

Eigil Pedersen has a B.A. from Sir George Williams University, an M.A. from McGill University, and an Ed. D. from Harvard University. He was a Professor at McGill for 30 years and held several administrative positions at the university including Chair of the Department of Psychology and Sociology of Education, Dean of Students, and Vice-Principal (Academic). He has also been a Visiting Scholar at Harvard University, London University, and Brandon University, and has an LLD (Honoris Causa) from Concordia University. He is particularly interested in educational research, student-teacher relationships, and teacher influence.

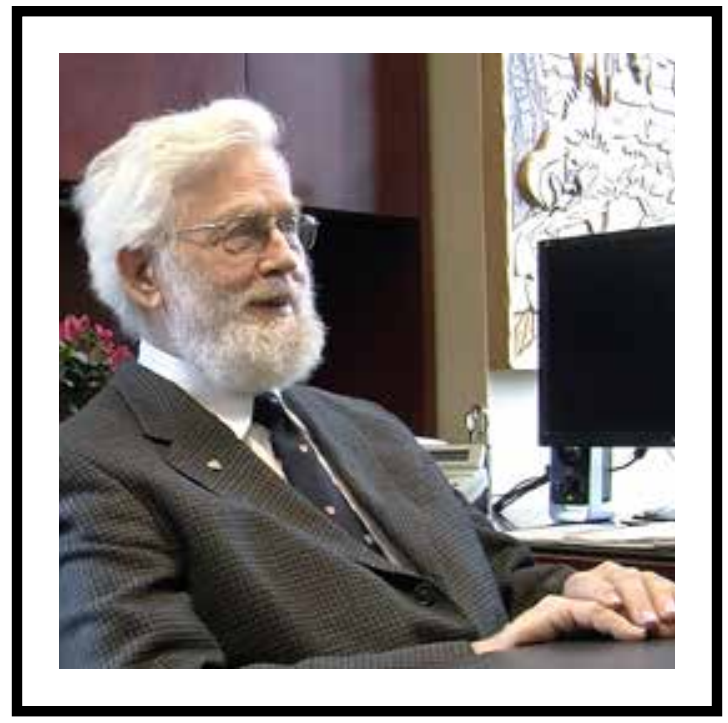

Click here to see an interview with Eigil Pedersen 